\title{
УГОЛОВНЫЙ ПРОЦЕСС
}

\section{А.В. Пиюк \\ К ВОПРОСУ О РОЛИ СУДА В ДОКАЗЫВАНИИ В СОВРЕМЕННОМ УГОЛОВНОМ ПРОЦЕССЕ РОССИЙСКОЙ ФЕДЕРАЦИИ}

\begin{abstract}
Рассматривается проблема обоснованности приговора суда. Действующий УПК РФ не предусматривает полномочий суда по самостоятельному истребованию каких-либо доказательств и требует от судьи лишь обеспечить состязательность и равноправие сторон и оценить совокупность имеющихся в уголовном деле доказательств. Представляется, что суд не должен быть связан позицией «состязающихся» субъектов процесса (сторон) и ограничиваться лишь исследованием представленных ими доказательств. Право суда по истребованию недостающих, по его мнению, доказательств нельзя трактовать исключительно как продолжение обоснования обвинительного тезиса, суд как орган правосудия должен с несомненностью устанавливать реальные обстоятельства деяния. УПК РФ необходимо дополнить нормой, предусматривающей право суда по окончании судебного следствия, после представления обвинителем и защитником доказательств, поставить на обсуждение вопрос об истребовании каких-либо доказательств, представляющихся судье необходимыми для правильного разрешения уголовного дела и устранения сомнений относительно каких-либо обстоятельств, подлежащих доказыванию, а также наделить суд правом истребования письменных и вещественных доказательств, необходимых для правильного разрешения уголовного дела, и правом вызова свидетеля совершенного (либо несовершенного) деяния по собственной инициативе.
\end{abstract}

Ключевые слова: уголовный проиесс, активность суда, доказательства и доказывание, исследование доказательств судом, общий порядок судебного разбирательства.

Как известно, согласно ст. 20 УПК РСФСР 1960 г., действовавшего до принятия УПК РФ 2001 г., суд, прокурор, следователь и лицо, производящее дознание, были «обязаны принять все предусмотренные законом меры для всестороннего, полного и объективного исследования обстоятельств дела, выявить как уличающие, так и оправдывающие обвиняемого, а также смягчающие и отягчающие его ответственность обстоятельства». Статья 71 УПК РСФСР также устанавливала, что основой оценки доказательств судом, прокурором, следователем, органом дознания выступает «всестороннее, полное и объективное рассмотрение всех обстоятельств дела в их совокупности».

В УПК РФ законодатель закрепил иной подход, указав в ст. 17 УПК РФ, что судья и иные субъекты судопроизводства оценивают доказательства по своему внутреннему убеждению, основанному «на совокупности имеющихся в уголовном деле доказательств, руководствуясь при этом законом и совестью». Известно также, что ч. 3 ст. 15 УПК РФ гласит, что суд не выступает на стороне обвинения или стороне защиты, он создает необходимые условия для исполнения сторонами их процессуальных обязанностей и осуществления предоставленных им прав. Частью 1 ст. 243 УПК РФ закреплено, что председательствующий судья руководит судебным заседанием, принимает все предусмотренные Кодексом меры по обеспечению состязательности и равноправия сторон. Согласно ст. 274 УПК РФ, доказательства представляются сторонами, первой представляет доказательства сторона обвинения. В соответствии с ч. 3 ст. 278 УПК РФ судья задает вопросы свидетелю после допроса его сторонами, правом вызова свидетеля по своей инициативе суд при этом не наделен.

Таким образом, прежним законодательством суду, как и иным субъектам процесса, наделенным государственно-властными полномочиями, предписывалось принимать все предусмотренные законом меры к всестороннему, полному и объективному исследованию обстоятельств дела и установлению истины, действующий же УПК РФ требует от судьи лишь обеспечить состязательность и равноправие сторон и оценить совокупность имеющихся в уголовном деле доказательств.

Значит ли это, что суд должен быть связан лишь позицией «состязающихся» субъектов процесса (сторон) и ограничиваться только совокупностью представленных ими доказательств?

Нам представляется, что нет, поскольку суд - это орган, отвечающий за законность и справедливость приговора.

Посмотрим на требования, предъявляемые законодателем к приговору. Согласно ч.1 ст. 297 УПК РФ, приговор должен быть законным, обоснованным и справедливым. Частью 4 ст. 302 УПК РФ установлено, что обвинительный приговор не может быть основан на предположениях и постановляется лишь при условии, что в ходе судебного разбирательства виновность подсудимого в совершении преступления подтверждена совокупностью иссле- 
дованных судом доказательств. Согласно ст. 299 УПК РФ, к числу вопросов, которые суд должен разрешить при постановлении приговора, относится и вопрос о доказанности вины лица в совершении преступления.

Более того, в ч. 1 ст. 49 Конституции РФ, имеющей высшую юридическую силу среди всех законов Российской Федерации, закреплено, что каждый обвиняемый в совершении преступления считается невиновным, пока его виновность не будет доказана в предусмотренном федеральным законом порядке.

Приговор суда всегда должен оставаться актом правосудия, лишь такой приговор будет уважаем в обществе. Профессор М.К. Свиридов, проанализировав нормы УПК РФ непосредственно после его принятия, абсолютно справедливо, на наш взгляд, указал, что в части общего порядка, в отличие от порядка особого, регламентированного гл. 40 УПК РФ, Кодекс ориентирован на установление материальной истины $[1$, с. 3].

Да, возможно, с учетом позиции законодателя, что это, в определенной мере, попытка выдать «желаемое за действительное», однако трудно отрицать очевидную схожесть норм УПК РФ и УПК РСФСР в части непосредственного исследования доказательств судом в общем порядке. Согласно положений ст.ст. 287, 288, 289, 290 УПК РФ, суд может инициировать и провести с участием сторон осмотр местности и помещения, следственный эксперимент, предъявление для опознания, освидетельствование, согласно ст. 283 УПК РФ, он также вправе назначить судебную экспертизу, в том числе и по своей инициативе. Если рассматривать вопрос об активности суда в исследовании доказательств, то очевидно, что в отношении рассмотрения дел в общем порядке Кодекс во многом воспроизводит положения, ранее присущие УПК РСФСР и в целом характерные для континентального типа процесса, к которому исторически относится российский уголовный процесс. Вместе с тем в УПК РФ отсутствует право суда на вызов свидетелей по собственной инициативе и право истребования каких-либо сведений, тогда как частью 4 ст. 276 УПК РСФСР, посвященной порядку разрешения ходатайств, было установлено, что суд вправе, независимо от того, заявлено ли об этом ходатайство участником процесса, вынести определение о вызове новых свидетелей, назначении экспертизы, истребовании документов и других доказательств, необходимых для правильного разрешения уголовного дела.

Известно, что незадолго до принятия УПК РФ конституционность данной нормы была оспорена в Конституционном Суде РФ, который в Определении от 23.01.2001 г. № 21-О «Об отказе в принятии к рассмотрению жалобы Якурина Константина Андреевича на нарушение его конституционных прав частью четвертой статьи 276 Уголовно-процессуального кодекса РФ» указал, что «...осуществление судом в публичном по своему характеру уголовном процессе функции правосудия не исключает на- личия у него права в рамках предъявленного подсудимому обвинения истребовать и исследовать доказательства, необходимые для проверки приводимых сторонами в обоснование своих позиций доводов... Иное не позволяло бы суду при рассмотрении уголовных дел давать объективную оценку отстаиваемым сторонами позициям и устранять возникающие в ходе судебного разбирательства сомнения в их обоснованности, а следовательно, не обеспечивало бы независимость суда при отправлении правосудия» [2].

Полагаем, что пришла пора привести несколько примеров.

Так, при рассмотрении уголовного дела по обвинению Р. в совершении преступления, предусмотренного ч. 1 ст. 105 УК РФ, следователем СУ СК РФ был допрошен лишь один из четырех свидетелей произошедшего деяния, причем находившийся на значительном расстоянии от места совершения преступления, допрос остальных следователь посчитал «нецелесообразным». Р. и его защитник настаивали, что Р. совершил убийство в состоянии аффекта. Несмотря на имевшееся в уголовном деле заключение судебно-психиатрической экспертизы, для правильной квалификации содеянного и устранения сомнений суду требовалось выслушать и оценить показания и иных очевидцев, однако следователь (и прокурор) суду их не представили, не ходатайствовал об их вызове и адвокат-защитник, считавший, что и так все ясно и все сомнения следует трактовать в пользу его подзащитного [3].

При рассмотрении уголовного дела по обвинению пенсионера Б. в совершении преступления, предусмотренного ч. 1 ст. 207 УК РФ, было установлено, что лицо, звонившее в дежурную часть ОМВД и сообщившее ложные сведения о заложенном в помещении Сбербанка РФ взрывном устройстве, активировало сим-карту, с которой был осуществлен звонок, путем перевода на нее средств в помещении управления соцзащиты населения, оборудованном камерами видеозаписи. Б. свою виновность в инкриминируемом деянии категорически отрицал, ходатайства же об истребовании видеозаписей от сторон не поступило и у суда также были определенные сомнения [4].

Сделаем небольшое отступление. Представляется, что в случаях, изложенных выше, суд мог вынести приговоры, основываясь на имеющихся доказательствах, причем приговоры эти были бы обвинительными, так как в деле по обвинению Р. имелась, помимо прочего, экспертиза, в которой указывалось, что он в момент убийства не находился в состоянии аффекта, а в деле по обвинению Б. наличествовали показания свидетелей, видевших Б. неподалеку от места, с которого был произведен звонок, а также свидетелей, показавших, что Б. покупал сим-карту оператора, из сотовой сети которого поступило сообщение. Мог суд также и объявить перерыв и в непроцессуальном порядке «понудить» какую- либо из так называемых «сторон» заявить соответствующее 
ходатайство. Именно так многие судьи, не видя возможности в установленном УПК РФ порядке устранить сомнения, и поступают на практике.

Не оправдывая подобное, полагаем, что УПК РФ должен предоставить судье возможность прийти к несомненному выводу. Думается также, что право суда по истребованию недостающих, по его мнению, доказательств нельзя трактовать исключительно как продолжение обоснования обвинительного тезиса, суд, как орган правосудия, прежде всего, должен устанавливать реальные обстоятельства деяния, устанавливать истину.

Данного термина бояться не следует. В Федеральных правилах о доказательствах США, страны, как считается, с исключительно состязательным построением процесса, к примеру, термин «истина» употребляется более сотни раз. Так, Правило 102 гласит: «Настоящие правила следует толковать в интересах обеспечения беспристрастного отправления правосудия... с целью установления истины и справедливого производства». Согласно Правилу 611, суд осуществляет контроль над способом и порядком допроса свидетелей и представления доказательств, в соответствии с Правилом 614 судья имеет право вмешиваться в представление доказательств сторонами, чтобы способствовать окончательному установлению истины, он имеет в том числе и право вызвать какое-либо лицо в качестве свидетеля по собственной инициативе [5].

Конечно, идеальным представляется вариант, при котором суд не истребовал бы никаких сведений и не вызывал бы никаких свидетелей, однако практика показывает, что идеала в реальной жизни достигнуть чрезвычайно сложно, таких дел, к сожалению, немного, в связи с чем суды и вынуждены прибегать к непроцессуальным мерам воздействия на защитников и прокуроров.

Представляется, что УПК РФ следовало бы дополнить нормой, предусматривающей право суда по окончании судебного следствия, после представления обвинителем и защитником доказательств, поставить на обсуждение вопрос об истребовании каких-либо доказательств, представляющихся судье необходимыми для правильного разрешения уголовного дела и устранения сомнений относительно каких-либо обстоятельств, подлежащих доказыванию. Данное предложение не ново, тот же професcop М.К. Свиридов еще в 2002 г., высказавшись против самостоятельного устранения пробелов судом, предложил при недостаточности доказательств предоставить суду право воздействовать на стороны, предложив им представить недостающие, по мнению суда, доказательства[1, с. 6].

Представляется также, что, сказав «а», следует сказать и «б». Что делать суду, если стороны все же не представят доказательства или откажутся выполнять какие-либо предложения суда? Исходя из того, что суд не имеет права вынести приговор, исчерпывающим образом не исследовав всю необходимую совокупность доказательств, следует, на наш взгляд, предоставить суду и право преодолеть пассивность либо несогласие субъектов процесса с истребованием каких-либо сведений или с вызовом свидетелей, обладающих сведениями об обстоятельствах деяния. Для этого суд необходимо наделить правом истребования письменных и вещественных доказательств, необходимых для правильного разрешения уголовного дела, а также предоставить суду право вызвать и допросить свидетеля совершенного (либо несовершенного) деяния по собственной инициативе.

\section{ЛИТЕРАТУРА}

1. Свиридов М.К. Состязательность и установление истины в уголовном судопроизводстве // Проблемы уголовного процесса в свете нового Уголовно-процессуального кодекса Российской Федерации / под ред. Ю.К. Якимовича. Томск: Изд-во Том ун-та, 2002. С. 3-6.

2. Определение Конституционного Суда РФ от 23.01.2001 г. № 21-О // Консультант Плюс [Электронный ресурс]: Справочная правовая система. Версия Проф, сетевая. Электрон. дан. М.: АО Консультант Плюс, 1992. Режим доступа: Компьютер. сеть Науч. б-ки Том. гос. ун-та, свободный.

3. Архив Мегионского городского суда ХМАО-Югры. Уголовное дело № 1-67/16.

4. Архив Мегионского городского суда ХМАО-Югры. Уголовное дело № 1-5/17.

5. Federal Rules of Evidens. Historical notes and legislative commentary // Published by the Legal Information Instittute. Cornell Law School. 1999.

\section{ON THE ROLE OF THE COURT IN PROVING IN THE MODERN CRIMINAL PROCESS OF THE RUSSIAN FEDERATION}

Ugolovnaya yustitsiya - Russian Journal of Criminal Law, 2017, no. 9, pp. 42-45. DOI 10.17223/23088451/9/8

Aleksey V. Piyuk, Megion City Court, (Megion, Russian Federation). E-mail: avaleks2@yandex.ru

Keywords: criminal procedure, activity of the court, evidence and proof, investigation of evidence by court, general procedure for litigation.

The paper dwells on the problem of reasonableness of a court decision. The current Code of Criminal Procedure of the Russian Federation does not provide for the powers of the court to independently demand any evidence and requires the judge only to ensure adversariality and equality of the parties and to evaluate the totality of evidence in the criminal case. It seems that the court should not be bound by the position of "adversarial" subjects of the process (parties) and confine itself to examining the evidence presented by them. The court's right to demand missing evidence can not be interpreted solely as a continuation of the justification of the accusational thesis. The court as an organ of justice must definitely determine the real circumstances of the act. The Code of Criminal Procedure of the Russian Federation should be supplemented with a rule providing for the right of the 
court at the end of the judicial investigation, when the prosecutor and defender have presented evidence, to discuss the issue of demanding any evidence that the judge deems necessary to properly resolve the criminal case and to remove doubts about any circumstances subject to proof, and also give the court the right to demand written and material evidence necessary for the correct resolution of the criminal offense and to summon a witness of the act on its own initiative.

\section{REFERENCES}

1. Sviridov, M.K. (2002) Sostyazatel'nost' i ustanovlenie istiny v ugolovnom sudoproizvodstve [Adversariality and the establishment of truth in criminal proceedings]. In: Yakimovich, Yu.K. (ed.) Problemy ugolovnogo protsessa v svete novogo Ugolovno-protsessual'nogo kodeksa Rossiyskoy Federatsii [Problems of the criminal process in the light of the new Code of Criminal Procedure of the Russian Federation]. Tomsk: Tomsk State University. pp. 3-6.

2. Constitutional Court of the Russian Federation. (2001) Opredelenie Konstitutsionnogo Suda RF ot 23.01.2001 g. № 21-O [Definition № 21-O of the Constitutional Court of the Russian Federation of January 23, 2001]. [Online] Available from: $\mathrm{http} / / /$ www.consultant.ru/document/cons_doc_LAW_40011/.

3. Khanty-Mansiisk Autonomous District. (n.d.) Archive of the Megion City Court of KhMAD-Ugra. Criminal case No. 1-67.

4. Khanty-Mansiisk Autonomous District. (n.d.) Archive of the Megion City Court of KhMAD-Ugra. Criminal case No. 1-5/17.

5. Legal Information Instittute. (1999) Federal Rules of Evidens. Historical notes and legislative commentary. Cornell Law School. 